\title{
Nasionalisme, Cinta, dan Kemurnian Etnik: Pertentangan adat dalam novel-novel pasca-kemerdekaan
}

\section{Rosyadah Khairani}

Prodi Pendidikan Bahasa \& Sastra Indonesia

UIN Syarif Hidayatullah Jakarta

Correspondence:

Rosyadah Khairani

Prodi Pendidikan Bahasa \& Sastra Indonesia

UIN Syarif Hidayatullah Jakarta rosyadahkhairani5@gmail.com

Article History:

Received 22 January 2021

Revised 19 April 2021

Accepted 27 April 2021

\begin{abstract}
This paper discusses the contradiction of adat in Marianne Katoppo's Raumanen and Marah Rusli's Memang Jodoh. Although Sukarno-Hatta's speech of the Proclamation (1945) was considered a momentum for the fusion of various ethnic groups in the archipelago in a community called Indonesia, apparently the primordial conflict typical of the Balai Pustaka novels cannot be reconciled just like that. The plural of Indonesian society still upholds primordial values and morals so that integration becomes a homework that is always challenging and never ends. This paper has the tendency to reveal colossal problems, namely marriage (read: romance) with a background of differences in customs in post-independence novels as a representation of the giddiness of the situation of Indonesian national integrity. Raumanen and Memang Jodoh as objects of research material will be discussed to trace how inter-adat marriages become a real picture of the dynamics of the recent nationality. By using a Swingewood conceptual framework, this paper concludes that Raumanen describes the social life of different ethnic communities which has the potential to eliminate the lineage of a nation through inter-adat marriage. Meanwhile, Memang Jodoh tells of marriages with ethnic differences that must be redeemed by the loss of traditional aristocratic privileges. But the sacrifice is considered worth it because the institution of marriage is about the inner happiness of the perpetrator.

Keywords:

Raumanen, Memang Jodoh, marriage, adat
\end{abstract}

\section{Abstrak}

Tulisan ini mengetengahkan ihwal pertentangan adat dalam Raumanen karya Marianne Katoppo dan Memang Jodoh karya Marah Rusli. Meskipun pidato Proklamasi (1945) SukarnoHatta dianggap sebagai momentum peleburan pelbagai etnis di Nusantara dalam sebuah komunitas bernama Indonesia, rupanya konflik primordial khas novel Balai Pustaka terebut tidak lantas dapat didamaikan begitu saja. Jamak masyarakat Indonesia masih memegang teguh nilai dan susila primordial sehingga integrasi menjadi pekerjaan rumah yang senantiasa menantang dan tak kunjung usai. Tulisan ini bertendensi untuk mengungkapkan persoalan kolosal, yakni pernikahan (baca: percintaan) dengan latar belakang perbedaan adat dalam novel-novel pasca-kemerdekaan sebagai representasi dari gamangnya situasi integritas kebangsaan Indonesia. Raumanen dan Memang Jodoh sebagai objek material penelitian akan dibahas untuk melacak bagaimana pernikahan beda adat menjadi gambaran riil seputar dinamika kebangsaan kiwari. Dengan menggunakan kerangka konseptual ala Swingewood, tulisan ini menyimpulkan Raumanen menggambarkan kehidupan sosial masyarakat yang berbeda suku berpotensi menghilangkan garis keturunan suatu bangsa melalui pernikahan beda adat. Sedangkan Memang Jodoh menceritakan pernikahan yang dilatari perbedaan suku harus ditebus dengan hilangnya previlise aristokrat tradisional. Namun pengorbanan tersebut dianggap sepadan karena lembaga pernikahan adalah tentang kebahagiaan batin pelakunya. Kata Kunci:

Raumanen, Memang Jodoh, pernikahan, adat 
Pendahuluan

Meskipun dominasi pengarang Melayu dianggap usai setelah memasuki tahun 50-an (Sumardjo, 1999), namun langgam yang mereka ciptakan dalam tiga dekade sebelumnya tidak lantas lenyap begitu saja. Langgam sastra yang dimaksud berupa corak penceritaan novel yang berpusat pada pertentangan adat. Dalam khazanah kesusastraan para pengarang novel Balai Pustaka yang didominasi penulis Minangkabau mengetengahkan persoalan seputar tradisional (Timur) yang dipertentangkan dengan modernitas (Barat) sebagai motif dominan pengkaryaan (Teeuw, 1967). Dengan berpegang teguh pada spirit romantisme Eropa para pengarang Balai Pustaka (1920-1942) kerapkali menceritakan kisah percintaan masyarakat Hindia yang menyongsong modernitas kolonial sebagai modus operandi yang paling digemari (Faruk, 2012). Novelnovel mereka disebut "roman protes Indonesia" karena gambaran kisah yang disajikan kerapkali menyindir dan bahkan mengejek dunia tradisional yang dianggap terbelakang, ketinggalan zaman, dan kolot (Abdullah, 1978).

Jejak-jejak pertentangan adat dalam kisah percintaan masyarakat Indonesia pascakolonial dapat ditemukan kembali dalam novel-novel seperti Raumanen karya Marianne Katoppo dan Memang Jodoh karya Marah Rusli. Di sisi lain, kisah perjodohanyang dibumbui pertentangan dikotomis kembali marak pada era 2000-an, bermetamorfosis dalam pertentangan ideologis di kalangan muslim, utamanya santri (Haryanti \& Fakhriyah, 2020). Fakta tersebut menjadi bukti an sich dan sekaligus meneguhkan jika spirit romantisme awal abad XX masih menjadi kesadaran literer pengarang Indonesia modern pasca-kemerdekaan. Dalam perspektif pascakolonial, wujud literer tersebut menggambarkan bahwa pengalaman masyarakat Indonesia merdeka yang belum beralih dari jejak- jejak kolonialisme yang menyebabkan kelas sosial Hinda-Belanda selalu tercerai-berai (Labrousse, 1982), modernisasi kolonial yang senantiasa diwarnai dikotomi antagonistik yang ambivalen (Foulcher \& Day, 2008), gejolak pertentangan antara yang tradisional dengan yang modern tak pernah terdamaikan (Faruk, 1999).

Terkait kecenderungan kesusastraan di atas tulisan ini akan menjabarkan fenomena lanjutan dari tradisi novel-novel Balai Pustaka, yakni kisah percintaan berlatar belakang perbedaan adat. Tujuannya untuk melihat konteks sosiologis masyarakat yang menjadi faktor determinan dibalik hadirnya sebuah karya sastra. Dalam tulisan ini Raumanen karya Marianne Katoppo dan Memang Jodoh karya Marah Rusli dipilih sebagai objek material penelitian.

Raumanen (1977) dan Memang Jodoh (2015) menceritakan pergumulan tokoh-tokoh yang memperjuangkan cinta dan kisah kasih yang tak sampai karena terhalang oleh adat budaya yang masih sangat kental di suatu daerah. Dalam konteks sosial Indonesia hari ini praktik pernikahan beda ada masih banyak ditentang di beberapa daerah. Sumir, pernikah lintas budaya dianggap menjatuhkan harga diri dan martabat keluarga. Seperti tampak pada Manen yang notabene keturunan Manado dan Monang yang berasal dari Batak dalam Raumanen. Pernikahan beda suku juga terjadi pada pasangan Hamli seorang laki-laki keturunan bangsawan Minang dengan Din Wati seorang perempuan keturunan bangsawan Sunda dalam Memang Jodoh. Kisah klasik seputar kasih tak sampai masih kerapkali terjadi pada daerah yang kental dengan adat budaya. Bentrokan budaya pada kedua novel ini sangat terasa dan mendalam dari segi aspek-aspek sosial-budaya. Potensi yang dikandung kedua teks novel tersebut dianggap relevan untuk dikaji. 


\section{Landasan Teori}

Sebagai sesuatu yang dramatis struktur karya, konflik mengacu pada pertarungan antara dua kekuatan yang seimbang dan menyiratkan aksi dan reaksi (Wellek \& Warren, 2016). Sebuah konflik akan tergolong sebagai unsur penting dan menjadi peristiwa fungsional, utama, atau kernel. Konflik dianggap sebagai unsur esensial dalam pengembanganplotsebuahtekssastra.Kemampuan pengarang untuk memilih dan membangun konflik melalui berbagai peristiwa (baik aksi maupun kejadian) akan sangat menentukan daya tarik cerita yang dihasilkan. Konflik biasanya menunjuk pada pengertian sesuatu (bagian) yang bersifat tidak menyenangkan yang dialami oleh tokohtokoh cerita (Nurgiyantoro, 2015). Konflik sosial merupakan perbedaan pikiran, pandangan, serta kepentingan seorang individu maupun kelompok dalam setiap tindakan sosial yang dilakukannya (Mustamin, 2016).

Swingewood (1972) menyatakan, bahwa dalam kerja analisis karya sastra seorang kritikus harus berhati-hati dengan slogan "sastra adalah cermin masyarakat". Sebab hal tersebut kerapkali mengabaikan peranan pengarang, terkait kesadaran dan tujuannya. Dalam melukiskan kenyataan, seniman tidak semata melukiskan keadaan sesunguhnya, tetapi mengubah sedemikian rupa kualitas kreativitasnya. Dalam hubungan ini Teeuw (2013) mengemukakan empat cara yang mungkin dilalui, yaitu (a) afirmasi, merupakan norma yang sudah ada; (b) restorasi, sebagai ungkapan kerinduan pada norma yang sudah usang; (c) negasi, mengadakan pemberontakan terhadap norma yang berlaku; dan (d) inovasi, mengadakan pembaharuan terhadap norma yang ada. Lalu, sehubungan dengan sastra (teks) dan sosiologi (konteks) Swingewod (1972) mempunyai cara pandang bahwa suatu jagad yang merupakan tumpuan kecemasan, harapan, dan aspirasi manusia, karena di samping sebagai makhluk sosial budaya akan sangat sarat termuat dalam karya sastra. Hal inilah yang menjadi bahan kajian dalam telaah sosiologi sastra.

Dalam studi sastra, sosiologi sastra didefinisikan sebagai salah satu pendekatan yang memahami dan menilai karya sastra dengan mempertimbangkan segi-segi kemasyarakatan (Damono, 1978). Sosiologi sastra memahami fenomena sastra dalam hubungannya dengan aspek sosial sebagai pendekatan atau cara membaca dan memahami sastra yang bersifat interdisipliner (Wiyatmi, 2013). Sebagai ilmu, sosiologi mempelajari hubungan dan pengaruh timbal balik antara aneka macam gejala sosial, misalnya gejala ekonomi, gejala keluarga, dan gejala moral. Dalam hal ini sosiologi adalah ilmu yang mempelajari hubungan dan pengaruh timbal balik antara gejala sosial dengan gejala nonsosial. Juga, sosiologi adalah disiplin ilmu yang mandiri mempelajari ciri-ciri umum semua jenis gejalagejala sosial lain (Soekanto, 2017).

Dalam tulisan ini metode yang digunakan teori sosiologi Swingewood. Berkaitan dengan sastra dan masyarakat, Swingewood menyajikan tiga konsep dalam pendekatan, yaitu sastra sebagai refleksi/cerminan jaman, sastra dilihat dari proses produksi kepengarangannya, dan sastra dalam hubungannya dengan kesejarahan (Wahyudi, 2013).

\section{Hasil dan Pembahasan}

Memang Jodoh merupakan suatu bentuk protes atau keresahan sang penulis mengenai adat istiadat yang masih berlaku di suatu daerah. Ia menyuarakan tentang pernikahan yang dilarang oleh perbedaan suku. Pertentangan pernikahan karena adat tersebut mendatangkan persoalan sosial. Memang Jodoh merupakan suatu bentuk keresahan yang dirasakan pengarang 
sesuai dengan pengalaman hidup, yakni tidak menyetujui anjuran jika laki-laki Minangkabau melakukan poligami sebagai bentuk menurunkan kebangsawanan daerahnya. Hal tersebut terjadi kepada Marah Rusli dimana ayahnya menikah lagi dengan perempuan lain yang asli keturunan Minangkabau dan menyebabkan keharmonisan dan keutuhan keluarga menjadi hilang. Akhirnya Marah Rusli hanya tinggal berdua bersama ibunya semenjak ayahnya mempunyai istri baru.

Raumanen merupakan suatu bentuk dorongan dari sastrawan yang membuat ia menjadi semangat untuk menuliskan naskah ini sehingga tidak lagi disimpan di dalam laci seperti tulisan sebelumnya. Raumanen pernah menimbulkan kontroversi karena penggambarannya mengenai pasangan yang terhalang oleh suku dan adat suatu daerah yang membuat pembaca merasakan suatu ketegangan dari ceritanya. Kisah cinta dua orang pemuda yang sudah melanggar agama karena perbuatannya yang tidak senonoh ini juga mendatangkan permasalahan baru. Orang tua Monang tidak merestui hubungan yang dijalankan dengan perempuan berbeda suku dan membuat Manen merasa rakut dan khawatir sehingga memutuskan untuk mengambil jalan pintas dengan melakukan bunuh diri.

Raumanen menceritakan percintaan gadis Manado, Manen, dengan pemuda Batak, Monang, yang berakhir dengan kematian Manen. Perkenalan Manen dengan Monang bermula dalam suatu organisasi. Hubungan mereka bertambah mesra hingga Manen hamil. Monang berjanji akan menikahi Manen. Namun keluarga Monang yang masih berpegang teguh pada adat Batak bahwa Monang harus menikah dengan gadis sesukunya. Cintanya dengan Manen tidak direstui oleh ibunya. Raumanen mampu melukiskan pikiran yang paling dalam, yang merekam pengalaman emosional tokoh sampai ke taraf yang tidak terucapkan sangat efektif menggambarkan pertentangan tokoh dengan dirinya sendiri.

Permasalahan pertama yang terjadi disebabkan oleh Manen dan Monangyangmelakukan perbuatan yang dilarang oleh agama ketika mengikuti kegiatan di puncak. Pada awal perkenalan mereka, teman-teman Manen sudah menasihatinya untuk berhati-hati dan menjauhkan Monang, akan tetapi nasihat hanyalah sia-sia. Manen selalu memikirkan akan hal yang sudah kepadanya.

"Manen tahu apa maksud Monang. Kalau sudah cukup jauh dari lampu-lampu cemerlang di Jembatan Semanggi, akan dicarinya tempat sunyi. Sesudah ciuman di bukit Dago itu, Monang semakin berani belaiannya, semakin menuntut tindakannya. Dan Manen sendiri tidak mengerti. Mengapa dibiarkannya Monang menciumnya, mengelus-elus badannya seenaknya?" (1977: 59)

“Apa yang terjadi sesudah itu seakan-akan suatu mimpi buruk bagi Manen. Siapa yang akan dipersalahkannya? Penjaga bungalow, yang kebetulan sedang mencari kesempatan ngobjek di luar pengetahuan majikannya? Monang, yang begitu mahir merayu? Dirinya sendiri yang tak sanggup bertahan." (1977: 63)

Permasalahan itu semakin berlanjut dan akhirnya Manen memutuskan untuk datang ke dokter untuk melakukan pemeriksaan. Setelah diperiksa dokter menyatakan Manen positif hamil. Di satu sisi Monang sangat senang mendengar kabar tersebut karena ia memang menginginkan anak dari darah daginya sementara Manen semakin takut dan khawatir. Monang selau berusaha meyakini Manen untuk bertanggung jawab kepadanya hingga Monang memberitahukan kabar tersebut kepada ibunya dan minta untuk menikah dengan Manen.

"Raumanen, jangan menangis, Raumanen, aku akan 
bertangung jawab atas kejadian ini, kita kawin saja..."(1977: 63)

Setelah Monang memberitahu kabar tersebut kepada ibunya, ternyata ibunya sangat tidak menyetujui pernikahan tersebut. Ia melarang pernikahan yang dilakukan dengan perempuan yang berbeda adat. Ibunya hanya menyetujui Monang menikah dengan perempuan Batak pilihan ibunya. Hal tersebut membuat Monang berpikir untuk meminta Manen menggugurkan anak yang ada di kandungan Manen karena keluarganya tidak merestui hubungan tersebut.

"Tak usah begitu dramatis, Raumanen. Coba realitis dulu. Pikirkanlah, kau mau hidup dari apa nanti? Gajiku cuma 8000 rupiah sebulan, sangkamu kita bisa hidup dari gaji itu, apalagi kalau sudah ada anak nanti? Aku harus berusaha berdamai dulu dengan keluargaku. Dan kalau sekarang kita terus mulai dengan menyodorkan anak yang terlalu cepat lahir.... sulit sekali" (1977: 122)

Adat kebudayaan yang masih kental di suatu daerah menimbulkan suatu konflik sosial di masyarakat. Banyak daerah yang tidak memperbolehkan melakukan pernikahan dengan perbedaan suku. Hal tersebut akan dinilai sangat rendah sekali di daerahnya. Dalam Raumanen, Monang seorang laki-laki Batak tidak diperbolehkan menikah dengan suku lain karena kepercayaan ibunya yang masih sangat kuat. Ibunya hanya merestui jika ia juga menikah dengan sukunya karena sudah diatur dalam suatu ikatan adat yang bernama Dalihan Na Tolu.

"Monang tertawa, tapi nadanya tidak gembira. "Ah Raumaen! Kau begitu bodoh.... Calon-calon yang disodorkan oleh ibuku selalu gadis-gadis Batak yang paling cocok menurut hukum adat." (1977: 39)

Konflik semakin hari memuncak ditambah dokter kandungannya yang merupakan teman Manen yang bernama Philip menyarankan untuk menggugurkan anak tersebut karena walaupun dilahirkan akan tersebut tidak sempurna atau cacat yang diakibatkan oleh Monang yang memunyai sifilis. Hal itu terjadi karena Monang sering gontaganti perempuan dan berdampak kepada anak yang akan dilahirkannya nanti. Mengetahui kabar tersebut, Manen semakin terpuruk karena begitu banyak permasalahan yang terjadi ditambah keluarga Monang tidak menyetujui pernikahan yang akan dilakukan dengannya.

"Dengar, Manen. Anakmu takkan mungkin sehat. Wasserman test ternyata positif." (1977: 125)

“Tetapi kalau aku berjalan terus di jalan yang kini terpaksa kutempuh... terpaksa kubunuh anakku yang tak bersalah. Kata Philip anakku itu pasti akan cacat. Aku pernah belajar ilmu kesehatan di sekolah, dan aku tahu betapa ngerinya bentuk cacat yang disebabkan oleh penyakit sifilis keturunan." (1977: 126)

Konflik sudah mulai mereda dan akhirnya Manen menyadari bahwa hubungannya dengan Monang tidak dapat dilanjutkan karena adanya perbedaan adat. Ia sudah putus asa dengan keadaan yang terjadi kepadanya ditambah ia merasa kalau teman-temannya menjauhkannya ketika mengetahui ia mengandung anak dari Monang dari hubungan yang sudah dilarang oleh agama. Manen semakin terpuruk dan merasa berdosa kepada ibunya karena tidak dapat menjaga amanah yang diberikan kepadanya. Manen berpikir bahwa kematian adalah jalan yang tepat untuk hidupnya dan akhirnya ia memilih jalan pintas untuk mengakhiri hidupnya dengan melakukan bunuh diri.

"Dan tiba-tiba dianggapnya dirinya menjadi makhluk yang terhina, terkeji, yang pernah hidup di dunia." (1977: 126) 
"Tetapi pisau itu sudah jatuh ke lantai. Dan Raumanen terkapar di atas ranjang, menutup mukanya dengan kedua belah tangannya. Dan darah yang mengalir dari pergelangan tangannya, dalam remang-remang cahaya bulan itu, tampaknya seperti pita-pita merah yang sangat indah, yang tak pernah dapat disambung lagi." (1977: 128)

Monang merasa bersalah ketika mengetahui Manen bunuh diri. Ia menyesal karena sudah mencampakkan kekasihnya dan memberi beban derita yang ditanggungnya sendiri. Rasa bersalahnya semakin hari menjadi sebuah beban Monang karena selalu kepikiran betapa kejamnya ia sudah membuat Manen bunuh diri karena penderitaannya yang sangat mendalam.

"Setiap hari kurasakan hukumanNya itu. Pagi hari, bila bangun disambut wajah cemberut istri pilihan ibuku. Malam hari, bila terlelap tersiksa impian keindahan hari-hari lampau itu. 0, celakanya manusia! Yang sudah memegang kebahagian dalam kedua telapak tangannya lalu mencampakkannya, memijaknya karena mengejar kepalsuan dunia ini! Raumanen takkan penah kembali kepadaku. Dan lebih dari itu". (1977: 79)

Kisah percintaan yang dialami pasangan Monang dan Manen berakhir pilu karena hubungan yang dijalankan tidak sehat akibat perbuatan yang dilakukannya tidak senonoh dan dilarang oleh agama. Kisah cinta tersebut juga bertepuk sebelah tangan diakibatkan adanya penghalang untuk pernikahan mereka yaitu perbedaan suku dan adat budaya di antaranya. Monang yang tidak memperjuangkan cintanya kepada Manen dan mencampakkannya begitu saja membuat Manen merasa terpuruk karena harus berjuang sendirian yang membuat Manen memutuskan untuk bunuh diri. Kisah cerita pasangan Monang dan Manen berakhir dengan tidak bahagia.
Memang Jodoh menceritakan tentang idealisme seorang pemuda bernama Marah Hamli yang memperjuangkan cinta yang dari awal diyakininya adalah jodohnya. Hamli sendiri adalah seorang Bangsawan Padang. Ayah Hamli juga merupakan Bangsawan Padang yang sangat terpandang. Ibu kandung Hamli sendiri adalah Bangsawan Jawa yang telah memutuskan untuk patuh dan taat kepada adat bangsawan Melayu.

Kisah cinta dalam novel berawal ketika Hamli sedang menempuh pendidikan di ilmu pertanian Bogor dan tinggal bersama neneknya. Setelah beberapa bulan berkuliah, ia jatuh sakit dan penyakitnya sulit untuk disembuhkan. Setelah bertemu dengan perempuan keturunan Sunda yang bernama Din Wati ia sembuh dan tidak merasa sakit lagi. Melihat hal itu, nenek Hamli berniat untuk menikahkan mereka akan tetapi kabar tersebut terdengar oleh keluarga Hamli di Padang. Keluarganya sangat tidak menyetujui jika Hamli seorang bangsawan Padang menikah dengan perempuan bangsawan Sunda. Karena perbedaan adat tersebut membuat pernikahan mereka menjadi terhalang. Keluarga Hamli masih memercayai akan pernikahan dengan perbedaan adat akan memutuskan keturunan bangsawan mereka dan akan dipandang rendah.

"Laki-laki Padang tak diizinkan kawin dengan perempuan yang bukan suku Padang. Dipandang sangat hina apabila seorang laki-laki, lebih-lebih perempuan, kawin dengan orang yang berasal dari daerah lain. Oleh karena itulah perkawinan campuran biasanya tidak tahan lama dan tak dapat dipertahankan, segera putus kembali karena ia membawa beberapa halangan dan dihalang-halangi" (1961: 155).

"Saya telah malu dihinakan kemenakan yang tak mau menuruti kemauan mamaknya dan telah melanggar adat lembaga negerinya. Bukan itu gunanya saya 
pelihara dan saya besarkan dia, dari kecil sampai besar, dan dari bodoh sampai pandai, dengan kasih sayang dan penyelenggaraan yang lebih dari anak kandung saya sendiri. Ini balasannya. Sungguh, air susu dibalas air tuba" (1961: 252).

Pernikahan keduanya awalnya tidak disetujui dari kedua belah pihak karena memiliki kesan kurang baik. Keluarga Din Wati melarang anaknya untuk menikah dengan Hamli karena beranggapan bahwa Hamli orang jauh yang kemungkinan setelah menikah nanti Din Wati sudah tidak ada kabar lagi setelah dibawa kepada keluarganya di Padang. Sementara bagi keluarga Hamli yang keturanan bangsawan Minangkabau merupakan suatu hal yang sangat hina. Laki-laki Padang tidak diperbolehkan menikah dengan perempuan di luar adatnya.

"Perempuan negeriku menjadi seperti itu karena peraturan keibuan yang dipakai di sana. Perempuanlah yang memegang peranan penting dalam kehidupan rumah tangga mereka. Adat ini memang ada baiknya, karena pengaruh luar tak mudah masuk ke dalam masyarakat Padang, sehingga harta pusaka mereka misalnya dapat tersimpan dan tak jatuh ke tangan orang datang. Namun, berlebih-lebihan dalam halini, menyebabkan ia tak mudah disesuaikan dengan zaman yang telah beralih dan musim yang telah bertukar ini". (1961: 172).

Ibu Hamli merasa takut jika ia akan disalahkan oleh keluarganya di Padang karena menganggap bahwa ia tidak dapat menjaga anaknya hingga dapat menikah dengan perempuan yang bukan dari bangsawan Padang.

"Apa yang akan dikatakan mamaknya Baginda Raja dan kaum keluarga kita di Padang ini atau kaum keluarga ayahanda dan bangsawan Padang, jika mereka mendengar Hamli telah kawin dengan orang
Jawa? Tentu aku yang akan mereka salahkan. Aku yang tak dapat menjaga anak, aku yang tak tahu mendidik anak, sampai jatuh ke tangan perempuan negeri lain, memberi aib dan malu bangsawan Padang, sedangkan aku tak tahu apa-apa dalam perkawinan ini." (1961: 229)

Keluarga Hamli yang di Padang meminta ia menceraikan istrinya atau melakukan poligami dengan perempuan asal Minangkabau karena dianggapnya Hamli sudah menjatuhkan harkat martabat keluarga besarnya yang terpandang di Padang. Jika Hamli tidak menuruti perintah dari keluarganya, ia akan diusir dari daerahnya dan tidak diperbolehkan untuk kembali lagi. Hamli yang bersikap tegas untuk mempertahankan pernikahannya dengan Din Wati akhirnya tidak menuruti kemauan keluarganya sehingga ia dikeluarkan dari tanah kelahirannya. Walaupun ia merasa tenang dan lebih memilih untuk mempertahankan rumah tangganya, ia juga merasa menyesal karena tidak dapat pergi dengan membawa ibunya.

"Karena, barang siapa di antara anak cucu kami yang tak dapat mengikuti adat istiadat yang harus kami pegang teguh karena inilah kewajiban kami, terpaksa kami ceraikan pula. Kami orang Padang, orang berkampung bernegeri, orang beradatistiadat, bukan orang hutan yang tak punya aturan, tak patut mereka tinggal di lingkungan kaum keluarga kami." (1961: 365)

Dari kutipan di atas tampak Hamli dengan tegas sudah memutuskan untuk mempertahankan pernikahannya dengan Din Wati walaupun ia harus diusir dari tanah kelahirannya. Pernikahan Hamli dan Din Wati dianggap sebagai suatu bentuk kehinaan yang dirasakan oleh keluarga Hamli di Padang. Walaupun demikian, pernikahan mereka langgeng hingga akhir. Pernikahan 
yang dilandaskan bukan karena perihal nafsu belaka melainkan takdir yang sudah ditentukan memberikan kebahagiaan di dalam rumah tangga mereka karena Hamli percaya bahwa Din Wati memang jodoh yang sudah ditakdirkan oleh Allah dengan perjuangan-perjuangan yang dilakukan oleh Hamli walaupun banyak penghalang dari beberapa pihak terutama perbedaan suku adat dari keluarganya di Padang.

\section{Konteks Sosiologis Novel}

Fenomena kawin beda adat kerapkali tampak dalam karya sastra tradisi Balai Pustaka. Pada saat itu beberapa karya mengisahkan tentang kisah kasih yang tidak tuntas karena terkekang adat. Hal ini terjadi karena pada era Balai Pustaka tidak ada karya yang menyinggung pemerintahan, sedangkan selain itu bisa terbit. Dalam hal ini banyak pengarang yang akhirnya memilih untuk jenis karya yang berkisah tentang percintaan antaradat.

Kisah percintaan seperti ini kerap terjadi di masyarakat, baik masa lampau hingga masa kini. Namun, di era globalisasi dan maraknya arus teknologi di masa ini menjadikan percintaan beda suku atau adat tersebut semakin banyak terjadi meski masih ada batas-batas yang memberi mereka rambu-rambu yang jelas seperti norma agama. Norma-norma agama dianggap lebih penting daripada norma-norma suku atau adat lantara norma-norma suku atau adat masih bisa "ditekuk" atau "dibengkokkan" selama tidak melanggar ketentuan utama yang telah digariskan.

Adat mendapatkan kesahihannya dari masa lampau, yaitu masa ketika nenek moyang membangun pranata yang berlaku tanpa batas waktu (Muchtar, 2009). Adat dijalankan sebagai kebiasaan sehari-hari dan juga diwariskan turuntemurun sehingga daya hidupnya masih terjaga. Tidak mudah mengubah bahkan menghilangkan suatu adat di suatu daerah lantaran sudah menjadi bagian dari hidup mereka, baik jiwa maupun raga. Adat-adat itu pula yang memberikan sekat pada Monang-Manen dan Hamli-Din Wati sehingga kebebasan pernikahan mereka terbatas. Mereka hidup di zamannya namun masih menggunakan adat dari para sesepuh mereka.

Pernikahan beda budaya adalah suatu pernikahan yang terjadi antara pasangan yang berasal dari latar belakang budaya yang berbeda, di mana terdapat penyatuan pola pikir dan cara hidup yang berbeda, yang bertujuan untuk membentuk rumah tangga yang bahagia dan kekal berdasarkan Ketuhanan Yang Maha Esa (Prabowo, 2006). Konteks kutipan itu sejalan dengan konteks kini yang dialami oleh anak-anak zaman yang masih melestarikan adat dan budaya mereka namun adat dan budaya mereka sudah tidak sekaku pada zaman dahulu. Percampuran darah yang berbeda suku dan budaya bisa terjadi kapan pun selama para orang tua dan keluarga besar mereka merestui pernikahan itu lantaran tiada pantangan pokok yang terlanggar. Namun, Monang-Manen dan Hamli-Din Wati tidak bisa terlepas dari adat mereka karena mereka masih dianggap sebagai properti adat mereka yang harus menjaga nama baik adat di sana. Jalan yang ditempuh oleh kedua pasangan itu memang tetap bisa menyucikan adat yang masih lestari, namun kedua pasangan itu tidak bisa berdamai dengan adat-adat mereka.

Budaya tidak bisa dipahami sebagai suatu hukum kebiasaan belaka. Keragaman makna yang terwujud dalam budaya merentang dari cita rasa makanan, desain arsitektur, gaya berbusana, bertutur dengan dialek tertentu, serta berbagai pernik seremonial. Kultur itu sendiri adalah seperangkat sikap, perilaku dan simbol yang dianut oleh satu kelompok orang dan biasanya dikomunikasikan dari satu generasi ke generasi selanjutnya (Shiraev \& Levy, 2016). Pernyataan 
Shiraev tersebut sejalan dengan apa yang terjadi kepadakedua pasangan tersebut.Sejakkecilmereka berada di bawah payung adat yang menaungi mereka sehingga daya magnet peradatan tersebut masih sangat kuat. Generasi terkini terkadang menemui suatu kontradiksi antara adat mereka dengan arus modernisasi dan globalisasi sehingga mereka mengalami kebimbangan maupun dilema berat. Mereka dihadapkan kepada pilihan-pilihan tak mudah yang berimbas kepada ditinggalkannya pilihan lain. Pilihan-pilihan itu terkadang dilandasi dengan pemikiran logis dan mendalam, namun ada juga yang tidak.

Masyarakat dan berbagai institusinya diciptakan dan dipertahankan atau diubah melalui tindakan dan interaksi manusia (Johnson, 1986). Perubahan itu sejalan dengan iklim dan cuaca kemanusiaan yang menyelimuti perjalanan budaya dan adat istiadat di suatu daerah. Ada budaya dan adat istiadat yang tidak bisa berubah, sedikit atau sebagian berubah, serta ada pula yang dengan mudahnya bisa berubah. Semua itu ditentukan oleh manusia yang memiliki budaya dan adat istiadat tersebut, khususnya para pemangku budaya dan adat istiadat. Sebagai contoh, dulu seorang adik tidak boleh menikah terlebih dahulu jika kakaknya belum menikah. Namun di zaman sekarang hal tersebut mulai terkikis atau bahkan tidak berlaku lagi. Monang-Manen dan Hamli-Din Wati hanyalah anggota suatu kebudayaan atau adat istiadat. Posisi mereka juga belum berada pada posisi strategis sehingga langkah berbeda yang mereka ambil menjadi aib bagi adat tersebut. Langkah yang mereka tempuh tentu bisa dihargai dalam kacamata demokrasi, namun saat itu penghargaan tersebut belum sampai kepada mereka. Daya tawar mereka masih rendah dan hanya bisa mengikuti arus peradatan semata. Oleh karena itu, mereka harus memilih di antara dua pilihan dan tak bisa meleburkan pilihan tersebut menjadi sebuah kebahagiaan tunggal.

Dari hubungan-hubungan ini tidak mustahil akan terjadi perkawinan antarsuku, ras, dan agama dalam kehidupan masyarakat. Masyarakat Indonesia dikenal dengan masyarakat yang pluralistik atau majemuk dilihat dari segi etnik, agama, adat istiadat, maupun golongan. Karakteristik seperti ini mengakibatkan terjadinya interaksi sosial budaya yang pada gilirannya memunculkan fenomena perkawinan silang antaragama dan budaya serta etnis maupun golongan yang berbeda (Al Atthar, 1976).

Pernyataan Narsikun itu menjadi dasar bahwa peniadaan pernikahan beda suku di Indonesia ini tidak mungkin terjadi lantaran banyaknya suku yang berkembang dan hidup di negara ini. Jatuh cinta didasari rasa cinta atau rasa sayang, bukan rasa suku sehingga tidakmungkin membatasi orang harus mencintai seseorang dalam lingkup satu suku saja. Arus transportasi yang memungkinkan orang hinggap di luar negeri pun bisa menjadi pemicu munculnya kluster pernikahan beda negara. Maka, pernikahan pun dapat kita saksikan bisa menembus segala sekat-sekat perbatasan, baik antarsuku maupun antarnegara.

Sampai dengan saat sekarang, masih tetap berlaku ketentuan bahwa perkawinan itu hanya dapat dilakukan di antara anggota masyarakat yang sesuku, juga masih berlaku ketentuan bahwa perkawinan itu hanya dapat dilangsungkan antara mereka yang serumpun. Tetapi ketentuan kini tidak menutup kemungkinan untuk melakukan perkawinan dengan orang luar masyarakat itu, dengan cara melalui pengangkatan menjadi anggota masyarakat itu (Soekanto \& Taneko, 1983).

Sayangnya pernyataan Soekanto itu tidak sejalan dengan kehidupan Monang, kehidupan orang-orang Batak. Mereka menutup pintu untuk orang luar agar menjadi bagian dari mereka. 
Manen bisa memiliki Monang, namun Manen tidak bisa memiliki Batak. Sebenarnya ini ialah peluang bagus untuk Manen agar bisa diterima di keluarga Monang, namun tidak ada celah untuk menjadi bagian dari keluarga Monang. Monang akhirnya menyerah untuk tunduk kepada adatnya. Pilihannya memang tidak mudah, namun ia berani mengorbankan Manen.

Penyesuaian perkawinan adalah perubahan yang terjadi selama masa-masa pernikahan antara suami-istri untuk dapat memenuhi kebutuhan, keinginan, dan harapan masing-masing pihak, serta untuk menyelesaikan masalah yang ada sehingga kedua belah pihak merasakan kepuasan (Prabowo, 2006). Tetapi Hamli dan Din Wati tidak merasakannya. Mereka menjadi korban peradatan yang menekan dari kubu keluarga Hamli. Proses sinkronisasi antara Hamli dan Din Wati memang sudah terjalin dengan baik dan mereka sudah dalam posisi nyaman. Oleh sebab itu, keduanya memilih untuk tidak berpisah dan sanggup meninggalkan medan adat Mingakabau yang "mengekang" mereka, khususnya dari pihak Hamli. Mereka berdua berani dan sanggup memikul beban itu dan memperjuangkan masa depan milik mereka sendiri.

Di kalangan anggota keluarga masyarakat adat kekerabatan yang telah maju, orang tua atau keluarga telah dikalahkan oleh muda-mudi yang tidak lagi mau terikat dengan kehendak orang tua atau keluarga, tidak lagi membeda-bedakan asal-usul masyarakat adat seseorang untuk melakukan perkawinan sehingga banyak sudah terjadi perkawinan campuran antarsuku bahkan antargolongan penduduk walaupun jumlahnya masih belum begitu besar, tetapi lambat laun hal itu akan dianggap soal yang biasa saja (Hadikusuma, 2003).

Hamli dan Din Wati tidak salah jika saling mencinta. Mereka hanya korban peradaban yang masih memegang kemurnian suku asal Hamli, yaitu Minangkabau. Konstruksi pemikiran dan perilaku keluarga Hamli masih terkungkung dalam sangkar konservatif sehingga keluwesan Hamli dan Din Wati tidak menjangkau sangkar itu. Peristiwa itu menjadi representasi di masa itu bagaimana kekuatan peradaban yang dipertahankan oleh orang tua masih mencengkeram kuat untuk keturunan mereka. Gerak mereka tidak bebas bagai dirantai baja. Mau tidak mau mereka harus memilih untuktetap menghormati pernikahan atau menghormati peradatan. Maka, dengan terpaksa Hamli pun memilih setia untuk menghormati pernikahan.

Sistem perkawinan endogamiyaitumengadakan perkawinan satu sama lain di dalam klan mereka sendiri (antarkeluarga) karena hal ini dipandang dari segi sudut keamanan dan pertahanan, pemilikan tanah, kebun, sawah, serta dipandang dari segi sudut kemurnian darah/keturunan dan lain-lain pantangan yang bersifat magis religius (Muhammad, 2002). Hal ini terbukti berdasarkan kutipan data di atas di mana keluarga Hamli tidak ingin ada anasir dari luar yang bisa merugikan pihak dalam. Ini menunjukkan eksklusivitas yang dipertahankan oleh keluarga Hamli agar kemurnian darah mereka terjaga. Hal itu memang sah-sah saja dan juga memunyai dampak positif, namun Hamli tidak mengambil potensi itu. Hamli menjadi wakil anak muda zaman sekarang di mana ia hidup di zaman dahulu. Jika Hamli berbuat demikian, maka konteks sosial pada masa itu pun juga bisa disikapi seperti apa yang Hamli lakukan.

\section{Kesimpulan}

Adat budaya masyarakat yang masih kuat mendatangkan suatu kontroversi sosial yang di tengah masyarakat. Pernikahan dengan perbedaan suku dianggap suatu bentuk penghinaan berlatar kedaerahan. Dua novel yang dibahas menceritakan 
kisah perjuangan cinta yang terhalang oleh suku, adat, dan budaya. Dalam Raumanen akhir kisah cinta berakhir dengan pilu dan bertepuk sebelah tangan karena melakukan suatu perbuatan yang dilanggar oleh agama. Dari cerita ini mengajarkan bahwa perempuan haruslah bisa menjaga harga diri dan kehormatan dirinya. Perempuan harus bisa melawan tindakan-tindakan yang diperbuat oleh laki-laki yang tidak bermoral karena kehormatan perempuan sangatlah harus di jaga. Selain dari permasalahan yang timbul akibat perbuatan tidak senonoh tersebut, permasalah kedua yang timbul dari Raumanen ini yaitu karena perbedaan suku adat di antara mereka. Di akhir cerita Monang tidak memperjuangkan cintanya dan mencampakkan Manen dengan penderitaan yang dialaminya sehingga ia mengambil jalan singkat dan mengakhiri hidupnya dengan cara bunuh diri.

Dalam Memang Jodoh kisah perjuangan cinta berlatar belakang budaya yang berbeda. Di akhir cerita cinta Hamli dan Din Wati berakhir dengan bahagia walaupun banyak penghalang terutama dari keluarga Hamli di Padang yang sangat menetang pernikahan mereka. Dibanding mempertahankan status aristokrat Minangkabau, Hamli lebih memilih untuk mempertahankan pernikahannya dengan Din Wati yang sudang dianggapnya jodoh dan takdirnya walaupun ia harus diusir dari tanh kelahirannya dan tidak dapat kembali lagi.

\section{Daftar Pustaka:}

Abdullah, T. (1978). Ke Arah Pengenalan Sejarah Terhadap Sastra. In A. Rosidi (Ed.), Pesta Seni 1976 (pp. 107-122). Jakarta: Dewan Kesenian Jakarta.

Al Atthar, A. N. T. (1976). Poligami Ditinjau dari Segi Agama, Sosial, dan Perundang-undangan. Jakarta: Bulan Bintang.

Damono, S. D. (1978). Sosiologi Sastra Sebuah Pengantar Ringkas. Pusat Pembinaan Dan Pengembangan Bahasa Departemen Pendidikan Dan Kebudayaan Jakarta.

Faruk. (2012). Novel Indonesia, Kolonialisme, dan Ideologi Emansipatoris (Penerbit 0). Yogyakarta. Faruk, F. (1999). Mimikri Sastra Indonesia. Jurnal Kalam.

Foulcher, K., \& Day, T. (2008). Clearing a Space: Postcolonial Readings of Modern Indonesian Literature. Jakarta: KITLV-Jakarta.

Hadikusuma, H. (2003). Hukum Perkawinan Adat dengan Adat Istiadat dan Upacara Adatnya. Bandung: Citra Aditya Bakti.

Haryanti, N. D., \& Fakhriyah, F. N. (2020). Pesantren, Perempuan, dan Subaltern dalam Perempuan Berkalung Sorban dan Hati Suhita. SULUK: Jurnal Bahasa, Sastra, Dan Budaya, 2(2), 140-149. https://doi.org/10.15642/suluk.2020.2.2.140-149

Johnson, D. P. (1986). Teori Sosiologi: Klasikal dan Modern. Jakarta: Gramedia.

Katoppo, M. (1977). Raumanen. Jakarta: PT Dian Rakyat.

Labrousse, P. (1982). Le Tombeau de "Sitti Nurbaya”. Essai de lecture sociale. Archipel, 23(1). https://doi. org/10.3406/arch.1982.1731

Muchtar, R. (2009). Harmonisasi Agama dan Budaya di Indonesia. Jakarta: PT. Nusantara Lestari Ceriapratama.

Muhammad, B. (2002). Pokok-pokok Hukum Adat. Jakarta: Pradnya Paramita. 
Mustamin, M. (2016). Studi konflik Sosial di Desa Bugis dan Parangina Kecamatan Sape Kabupaten Bima Tahun 2014. Jurnal Ilmiah Mandala Education (JIME), 2(2), 185-205.

Nurgiyantoro, B. (2015). Teori Pengkajian Fiksi. Yogyakarta: Gadjah Mada University Press.

Prabowo, M. R. (2006). Penyesuaian Perkawinan Pada Pasangan Yang Berlatar Belakang Etnis Batak Dan Etnis Jawa. Universitas Gunadarma, Depok.

Rusli, M. (2015). Memang Jodoh. Jakarta: Balai Pustaka.

Shiraev, E. B., \& Levy, D. A. (2016). Psikologi Lintas Kultural: Pemikiran Kritis dan Terapan Modern (Keempat). Jakarta: Kencana Prenada Media Group.

Soekanto, S. (2017). Sosiologi: Suatu Pengantar. Depok: Rajawali Press.

Soekanto, S., \& Taneko, B. (1983). Hukum Adat Indonesia. Jakarta: Rajawali.

Sumardjo, J. (1999). Konteks Sosial Novel Indonesia 1920-1977. Bandung: Alumni.

Swingewood, A., \& Laurenson, D. (1972). The Sociology of Literature. United State: Paladin.

Teeuw, Andreas. (2013). Sastra dan Ilmu Sastra: Pengantar Teori Sastra. Jakarta: Pustaka Jaya.

Teeuw, Andries. (1967). Modern Indonesian literature. In Modern Indonesian literature. https://doi. org/10.1007/978-94-015-0768-4

Wahyudi, T. (2013). Sosiologi Sastra Alan Swingewood: Sebuah Teori. Poetika: Jurnal Ilmu Sastra, 1(1), 55-61. https://doi.org/10.22146/poetika.v1i1.10384

Wellek, R., \& Warren, A. (2016). Teori Kesusastraan. Jakarta: Kompas Gramedia.

Wiyatmi, W. (2013). Sosiologi Sastra: Teori dan Kajian terhadap Sastra Indonesia. Yogyakarta: Kanwa Publisher. 